ACTA UNIVERSITATIS NICOLAI COPER NICI

DOI: http://dx.doi.org/10.12775/AUNC_ECON.2014.015 EKONOMIA XLV nr 2 (2014) 235-251

Pierwsza wersja złożona 17 października 2014

ISSN

Końcowa wersja zaakceptowana 20 grudnia 2014

2080-0339

Anna Krzysztoń*

\title{
ANALIZA STANU ZASPOKOJENIA NIEKTÓRYCH POTRZEB SPOŁECZNYCH W ZALEŻNOŚCI OD ŹRÓDŁA UTRZYMANIA GOSPODARSTWA DOMOWEGO
}

Z a r y s t r e ś c i. Potrzeby społeczne klasyfikowane są według różnych kryteriów. Często przyjmuje się, że potrzeby podstawowe dotyczace egzystencji zaspokajane są w pierwszej kolejności. Celem artykułu jest sprawdzenie, które grupy gospodarstw domowych wyodrębnione ze względu na źródło utrzymania mają największe trudności finansowe związane z zaspokojeniem potrzeb niższego rzędu, a które mogą sobie pozwolić na swobodne zaspokajanie potrzeb wyższego rzędu.

S ło w a k 1 u c z o w e: potrzeby społeczne, analiza korespondencji, analiza skupień.

K 1 a s y fik a c j J E L: R22.

\section{WSTĘP}

Wielość i różnorodność potrzeb powoduje, że od lat starano się sklasyfikować je według kryterium podobieństwa. Jedną z najbardziej rozpowszechnionych teorii dotyczących potrzeb jest hierarchia potrzeb Maslowa (Doyal, Gough, 1991, s. 35). Ujętych zostało w niej pięć grup potrzeb, uporządkowanych od najbardziej podstawowych - fizjologicznych, poprzez potrzeby zapewnienia bezpieczeństwa, miłości i przynależności, szacunku i uznania, po potrzeby samorealizacji (Maslow, 2009, s. 62-71).

Potrzeba jest stanem zmiennym, powtarzającym się. Oznacza to, że przez cały czas mamy do czynienia z potrzebami związanymi np. z zaspoko-

\footnotetext{
* Adres do korespondencji: Anna Krzysztoń, Uniwersytet Ekonomiczny w Krakowie, Katedra Statystyki, ul. Rakowicka 27, 31-510 Kraków, e-mail: anna.krzyszton@tlen.pl.
}

(C) 2014 Uniwersytet Mikołaja Kopernika. All rights reserved. http://www.aunc.ekonomia.umk.pl 
jeniem głodu, z odpoczynkiem, ze spotkaniem z przyjaciółmi, z dbaniem o swoje zdrowie itd. Rzadko zdarza się, że można zaspokoić potrzebę w sposób ostateczny (np. w podróż dookoła świata wybiera się raz i potrzeba zostaje zaspokojona). Potrzeby związane $\mathrm{z}$ wyżywieniem, ochroną zdrowia, bezpieczeństwem zaspokajane są w sposób permanentny. Pomiędzy stanem zaspokojenia takiej potrzeby a jej pojawieniem się po raz kolejny występują krótkie okresy, kilkudniowe, a czasem kilkugodzinne. Potrzeby o zwiększonej częstotliwości występowania są ściśle związane z biologią człowieka, natomiast pozostałe potrzeby wynikają $\mathrm{z}$ relacji człowieka $\mathrm{z}$ otoczeniem. Zmienność potrzeb $\mathrm{w}$ czasie $\mathrm{w}$ mniejszym stopniu odnosi się do potrzeb podstawowych (np. wyżywienie, mieszkanie), a w większym do ponadpodstawowych (luksusowych) (Panek, 2007, s. 101). Potrzeby, które zarazem są podstawowe, ale jednocześnie społeczne, ulegają powolnym przeobrażeniom. Zmieniają się zwłaszcza procesy zaspokajania potrzeb i formy, w jakich potrzeby się objawiają (Kurzynowski, 2003, s. 52).

Potrzeba jest pojęciem dynamicznym i jako takie ulega ciągłemu rozwojowi, który dokonuje się na kilku poziomach. Ciągłe zmiany systemów środowiskowych, gospodarczych, społecznych i kulturalnych, w których człowiek funkcjonuje, sprawiają, że zmianom ulegają również potrzeby ludzkie. Wpływ na wzrost potrzeb, powstawanie nowych i ewolucję potrzeb już istniejących ma m.in. naśladownictwo krajów wyżej rozwiniętych, w których osiągnięty poziom rozwoju gospodarczego znacznie przyspiesza zarówno powstawanie nowych potrzeb, jak i rozwój nowych otoczek wokół potrzeb już istniejących. Również grupy „wzorcotwórcze”, które narzucają pewien styl i sposób zaspokojenia potrzeb, mają ogromny wpływ na ich kształtowanie (Szczepański, 1981, s. 147-151). Trudności finansowe związane z zakupem wyżywienia, mieszkania często nie pozwalają członkom gospodarstw domowych na właściwy rozwój kulturalny, intelektualny, dokształcanie się itp. Natomiast brak zaplecza intelektualnego hamuje postęp cywilizacyjny.

\section{CEL I ZAKRES BADAŃ}

Celem badania jest sprawdzenie, czy istnieją powiązania pomiędzy trudnościami finansowymi związanymi z zaspokajaniem niektórych potrzeb społecznych zgłaszanych przez gospodarstwa domowe a źródłem ich utrzymania. Dokonano analizy potrzeb z różnych szczebli hierarchii potrzeb, by zbadać, czy gospodarstwa domowe mają większe trudności finansowe związane $\mathrm{z}$ zaspokajaniem potrzeb niższego rzędu (potrzeby związane $\mathrm{z}$ zakupem artykułów żywieniowych, z ochroną zdrowia) niż z zaspokajaniem potrzeb wyższego rzędu (potrzeby związane z uczestnictwem w kulturze). 
Zakres rozważań dotyczy gospodarstw domowych objętych badaniem „Diagnoza społeczna” w latach 2003, 2007, 2011 i 2013. Szczegółowej analizie poddano potrzeby społeczne zgłaszane przez gospodarstwa domowe związane z wyżywieniem, ochroną zdrowia i kulturą. Pytania dotyczące wyżywienia zawarte w kwestionariuszach „Diagnozy społecznej” odnosiły się do trudności finansowych związanych z zakupem jedenastu towarów. Do analizy wybrano dwa produkty, dla których częstości zgłaszania trudności finansowych związanych $\mathrm{z}$ ich zakupem przez gospodarstwa domowe w rozważanych latach były najczęściej zbliżone do wartości mediany. Podobnie postąpiono z pytaniami dotyczącymi ochrony zdrowia i kultury.

$\mathrm{W}$ analizie uwzględniono następujące cechy:

- związane ze źródłem utrzymania gospodarstwa domowego': emeryci (EM), emeryci i renciści (ER $)^{2}$, gospodarstwa posiadające kilka źródeł utrzymania (KZ), gospodarstwa utrzymujące się z niezarobkowych źródeł (NZ), pracownicy posiadający gospodarstwo rolne (PG), pracownicy (PR), renciści (RE), rolnicy (RO), pracujący na własny rachunek (WR),

- związane z zakupem wybranych produktów lub usług: owoce i przetwory owocowe (Owoce), przetwory mięsne i drobiowe (PrzMi), leczenie szpitalne (Szpital), leczenie zębów (Zęby), kino (Kino), książka (Książ$\mathrm{ka}$,

- cecha dodatkowa - stały dochód (SD).

\section{METODYKA BADAŃ}

W badaniu wykorzystano wybrane metody wielowymiarowej analizy porównawczej: analizę korespondencji oraz analizę skupień. W literaturze przedmiotu zaleca się, by wyniki uzyskane w analizie korespondencji zweryfikować jedną z metod hierarchicznych (Stanisz, 2007; Gatnar, Walesiak, 2011). Zastosowanie tych metod ma na celu skojarzenie grup gospodarstw domowych (utworzonych ze względu na źródło utrzymania) oraz potrzeb społecznych, z których zaspokojeniem związane są trudności finansowe.

\footnotetext{
${ }^{1} \mathrm{~W}$ nawiasach podano kody cech stosowane w analizie, zostały one zróżnicowane pod względem trudności finansowych, tzn. jeżeli gospodarstwo domowe stać na zakup określonych usług, cecha otrzymuje symbol T (tak), jeżeli gospodarstwa nie stać na zakup usługi czy dobra, wówczas cecha otrzymuje symbol N, jeśli gospodarstwo nie zgłasza takiej potrzeby symbol ND (nie dotyczy), np. zapis Książka_T - oznacza, że gospodarstwo domowe stać na zakup książki i nie ma trudności finansowych związanych z tym konkretnym zakupem.

${ }^{2}$ Wśród rozważanych cech grupy emerytów i rencistów rozpatrywane są oddzielnie, wyjątkiem jest 2007 rok, w którym badanie „Diagnoza społeczna” przeprowadzono dla połączonej grupy emerytów i rencistów, stąd w przyjętych do analizy kodach pojawił się zapis ER.
} 
Zarówno analiza korespondencji, jak i analiza skupień umożliwiają wizualizację danych w postaci map percepcji oraz dendrogramów, co w znacznym stopniu ułatwia interpretację otrzymanych wyników oraz poznanie struktury populacji.

Na podstawie kryterium osypiska dokonano wyboru dwuwymiarowej przestrzeni rzutowania. Skumulowany procent bezwładności wyjaśnionej przez przyjętą dwuwymiarową przestrzeń wynosi ponad 90\%, czyli na tyle dużo, by została zachowana prawie pełna informacja o zróżnicowaniu wierszy i kolumn występujących w analizie korespondencji.

W dalszej części badania przeprowadzono analizę skupień na podstawie wartości współrzędnych punktów na mapie percepcji. Do weryfikacji wyników otrzymanych w analizie korespondencji zastosowano hierarchiczną metodę Warda (z kwadratową odległością euklidesową). Jej zaletą jest fakt, że przedstawia najbardziej naturalne skupiska elementów.

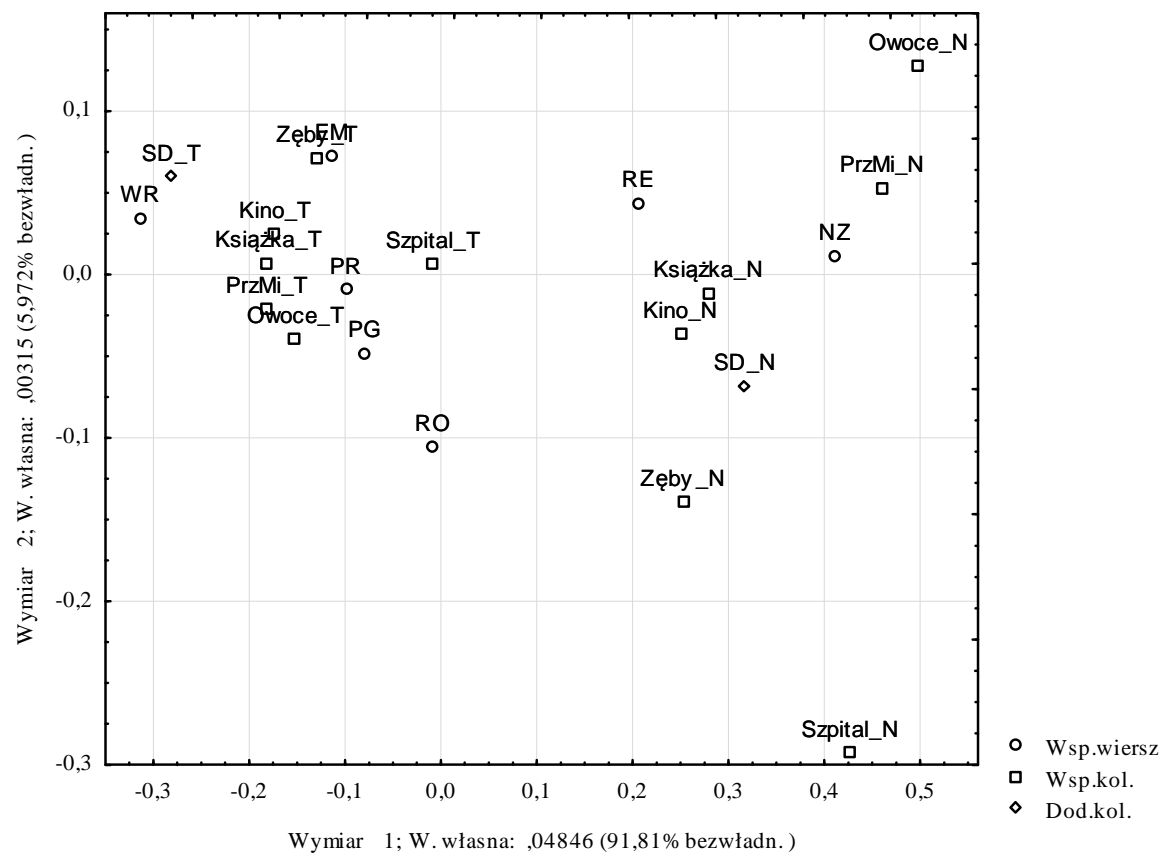

Rysunek 1. Prezentacja powiązań pomiędzy grupami gospodarstw domowych a trudnościami finansowymi dotyczącymi zaspokajania wybranych potrzeb społecznych w 2003 roku

Źródło: opracowanie własne. 


\section{WYNIKI BADAŃ}

Wyniki uzyskane na podstawie przeprowadzonych analiz przedstawiono na mapach percepcji i dendrogramach skonstruowanych osobno dla danych z poszczególnych lat.

Jak wynika z rysunku 1, oś pozioma reprezentująca pierwszy wymiar wyjaśnia większość zróżnicowania pomiędzy analizowanymi wierszami i kolumnami. Oś pozioma rozdziela dwie grupy potrzeb ze względu na fakt powiązania ich z trudnościami finansowymi. Wymiar 1 rozpięty jest przez punkty o najmniejszej masie, tj. przez Szpital_N (masa 0,004), Owoce_N (masa 0,039) oraz PrzMi_N (masa 0,047). Punkty reprezentujące gospodarstwa domowe rolników (RO), pracowników (PR) i pracowników posiadających gospodarstwo rolne (PG) usytuowane są blisko środka osi, co oznacza, że ich profile są zbliżone do profilu przeciętnego.

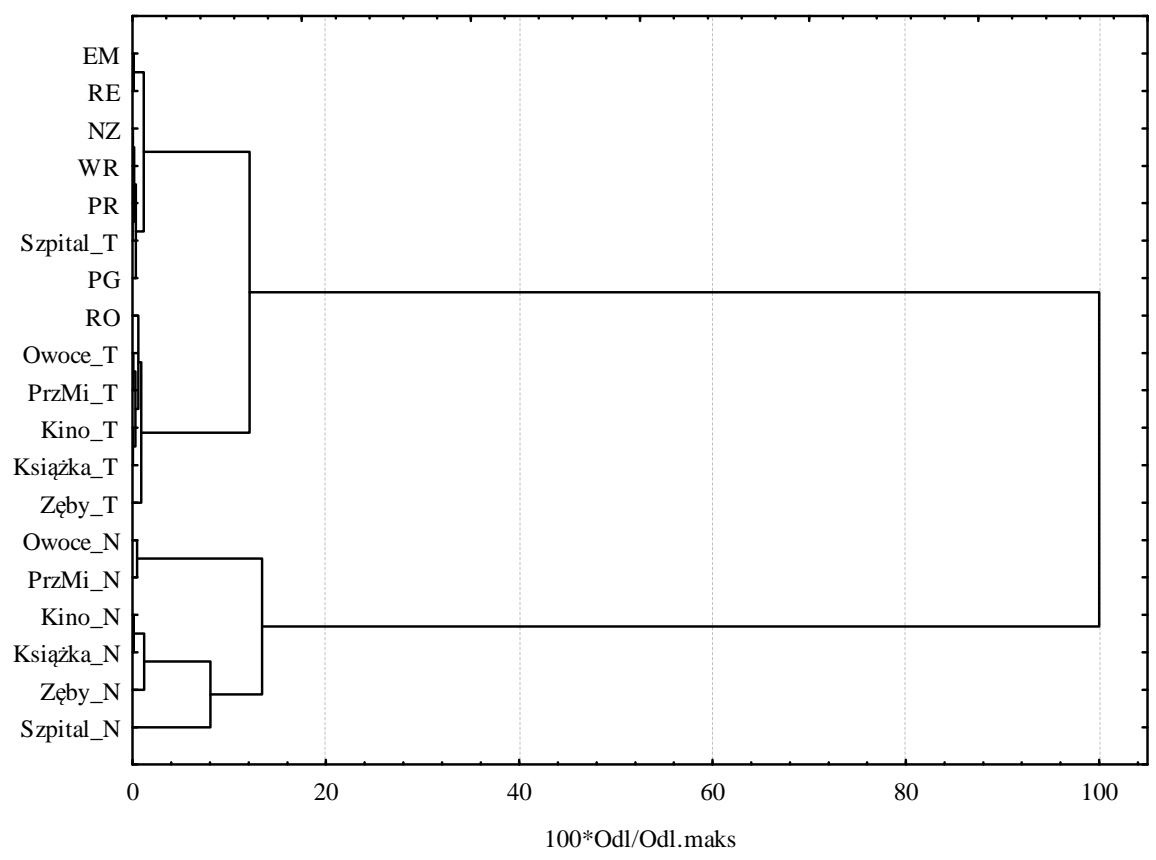

Rysunek 2. Skupiska grup gospodarstw domowych oraz wybranych potrzeb społecznych badanych w 2003 roku

Źródło: opracowanie własne.

Okazało się, że 16,31\% gospodarstw domowych biorących udział w badaniu nie miało trudności finansowych związanych z leczeniem szpitalnym, $12,77 \%$ stać było na zakup owoców, a 11,93\% mogło sobie pozwolić na 
kupno przetworów mięsnych. Gospodarstwa prowadzone przez rencistów (RE) oraz utrzymujące się z niezarobkowych źródeł (NZ) miały największe trudności związane $\mathrm{z}$ zaspokajaniem analizowanych potrzeb społecznych. Trudności te były większe, jeśli chodzi o zakup książki i biletu do kina, niż biorąc pod uwagę zakup artykułów spożywczych czy ochronę zdrowia związaną z leczeniem zębów bądź z pobytem w szpitalu.

W badaniu „Diagnoza społeczna” przeprowadzonym w 2003 roku nie sprawdzano, czy wśród gospodarstw domowych którakolwiek z analizowanych potrzeb nie dotyczy tego gospodarstwa bądź nie zgłasza ono zapotrzebowania na dany produkt czy usługę.

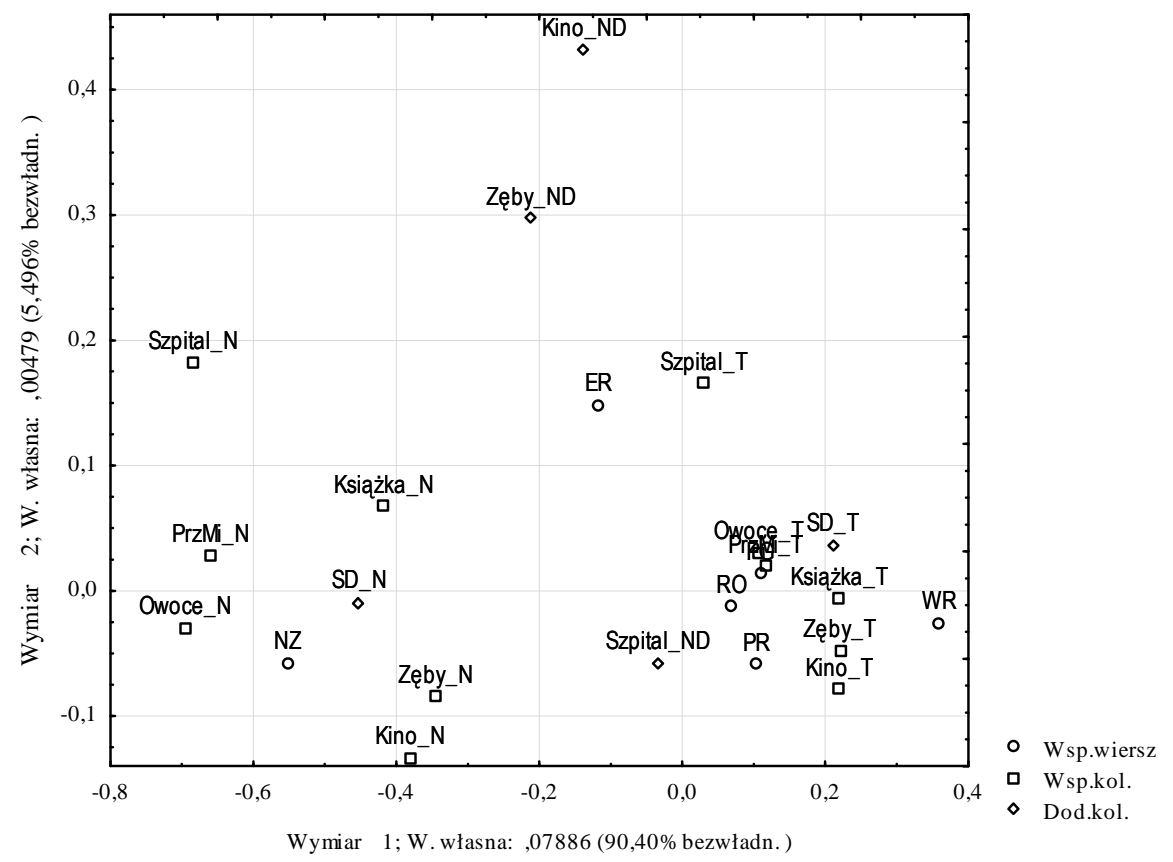

Rysunek 3. Prezentacja powiązań pomiędzy grupami gospodarstw domowych a trudnościami finansowymi dotyczącymi zaspokajania wybranych potrzeb społecznych w 2007 roku

Źródło: opracowanie własne.

Nie wszystkie zależności między kategoriami zmiennych można bezpośrednio odczytać z wykresu, dlatego posłużono się metodą Warda, która pozwala na łatwiejszą interpretację mapy.

$\mathrm{W}$ analizie skupień pominięto punkty dodatkowe - stały dochód (SD) oraz potrzeby $\mathrm{z}$ atrybutem ND (nie dotyczy). 


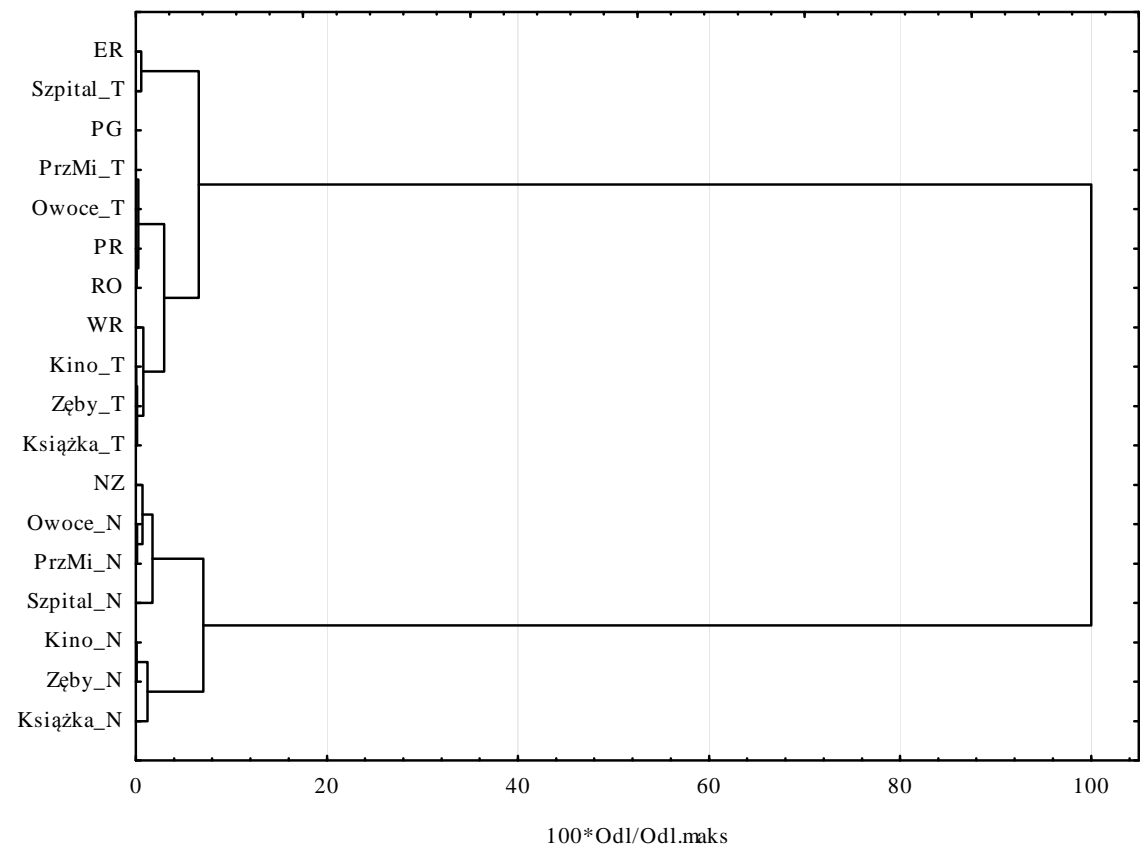

Rysunek 4. Skupiska grup gospodarstw domowych oraz wybranych potrzeb społecznych badanych w 2007 roku

Źródło: opracowanie własne.

Dendrogram przedstawiony na rysunku 2 pokazuje dwa skupiska. Do jednego $\mathrm{z}$ nich zaliczają się wszystkie kategorie cech $\mathrm{z}$ atrybutem $\mathrm{N}$, tzn. potrzeby społeczne, na których zaspokojenie gospodarstwa nie mogą sobie pozwolić ze względów finansowych. Natomiast w drugim skupisku Szpital_T został skojarzony z wszystkimi grupami gospodarstw domowych. Zaistniała sytuacja wynika z faktu, iż punkt Szpital_T ma największą masę spośród analizowanych kolumn $(0,163)$, a co za tym idzie, aż $16,3 \%$ badanych gospodarstw domowych nie zgłasza trudności finansowych związanych z leczeniem szpitalnym.

Spośród gospodarstw ankietowanych w 2007 roku jedynie $0,16 \%$ miało trudności finansowe związane z leczeniem szpitalnym, z zakupem owoców $3,14 \%$, przetworów mięsnych $-3,50 \%$. Na kupno wyżywienia bez problemów finansowych mogło sobie pozwolić ok. 17\% gospodarstw domowych, natomiast na zakup książki - ok. 13\%.

Gospodarstwa utrzymujące się z niezarobkowych źródeł (NZ) miały trudności z zaspokojeniem analizowanych potrzeb, zwłaszcza dotyczących 
wyżywienia. Emeryci i renciści (ER) byli grupą gospodarstw niezainteresowanych wyjściem do kina (Kino_ND) oraz leczeniem zębów (Zęby_ND). Pozostałe gospodarstwa stać było na zakup dóbr i usług związanych z wyżywieniem, ochroną zdrowia i kulturą.

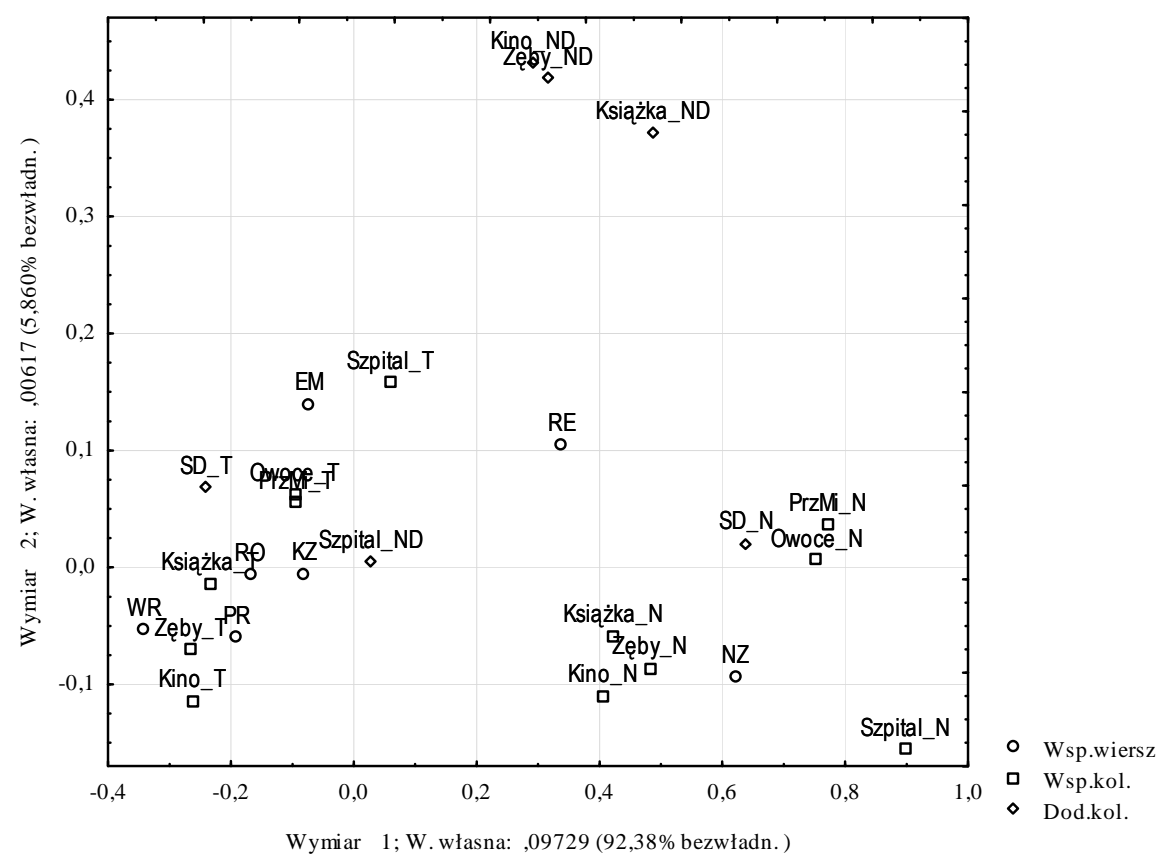

Rysunek 5. Prezentacja powiązań pomiędzy grupami gospodarstw domowych a trudnościami finansowymi dotyczącymi zaspokajania wybranych potrzeb społecznych w 2011 roku

Źródło: opracowanie własne.

Dendrogram przedstawiony na rysunku 4 , podobnie jak dla danych z 2003 roku, prezentuje dwa skupiska. Zauważyć można współwystępowanie gospodarstw utrzymujących się z niezarobkowych źródeł (NZ) oraz punktów reprezentujących wyżywienie, dopiero w dalszej kolejności następuje połączenie z punktami przedstawiającymi ochronę zdrowia i kulturę. Podobną zależność widać na rysunku 3.

Drugie skupisko tworzą wszystkie pozostałe rodzaje gospodarstw domowych oraz punkty $\mathrm{z}$ atrybutem $\mathrm{T}$, wynika $\mathrm{z}$ tego, że nie zgłaszały one trudności finansowych związanych $\mathrm{z}$ zakupem dóbr i usług związanych z wyżywieniem, ochroną zdrowia i kulturą. 
Na rysunku 5 zauważyć można, że gospodarstwa utrzymujące się z niezarobkowych źródeł (NZ) oraz gospodarstwa rencistów (RE) umiejscowione są po tej samej stronie osi poziomej co punkty, które świadczą o trudnościach finansowych związanych $\mathrm{z}$ zaspokajaniem rozważanych potrzeb w 2011 roku. Stały dochód nie wystarczał tym dwóm grupom gospodarstw na zakup potrzebnych dóbr i usług związanych z wyżywieniem, ochroną zdrowia i kulturą.

Spośród gospodarstw domowych biorących udział w badaniu ponad $18 \%$ mogło swobodnie zaspokajać swoje potrzeby związane $\mathrm{z}$ wyżywieniem, a na zakup książki mogło pozwolić sobie prawie 13\% gospodarstw. Mniej niż 1\% gospodarstw miało trudności finansowe związane $\mathrm{z}$ leczeniem szpitalnym, a prawie $4 \%$ - z zakupem wyżywienia.

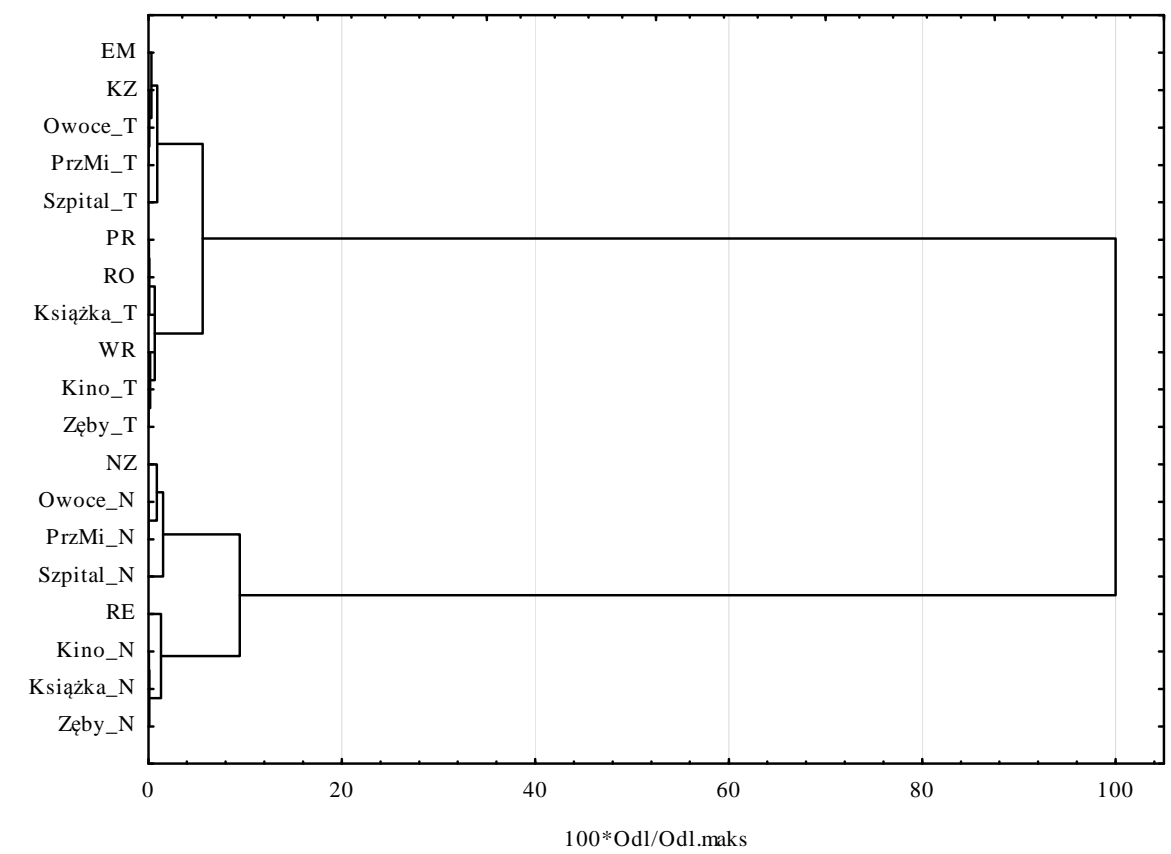

Rysunek 6. Skupiska grup gospodarstw domowych oraz wybranych potrzeb społecznych badanych w 2011 roku

Źródło: opracowanie własne.

Z zależności przedstawionych na rysunku 6 wynika, że w 2011 roku gospodarstwa utrzymujące się z niezarobkowych źródeł (NZ) miały największe trudności finansowe związane $\mathrm{z}$ zaspokojeniem potrzeb dotyczących wyżywienia i leczenia szpitalnego. $Z$ kolei gospodarstwa rencistów (RE) borykały 
się z problemami dotyczącymi braku środków finansowych na leczenie zębów, zakup biletu do kina czy książki.

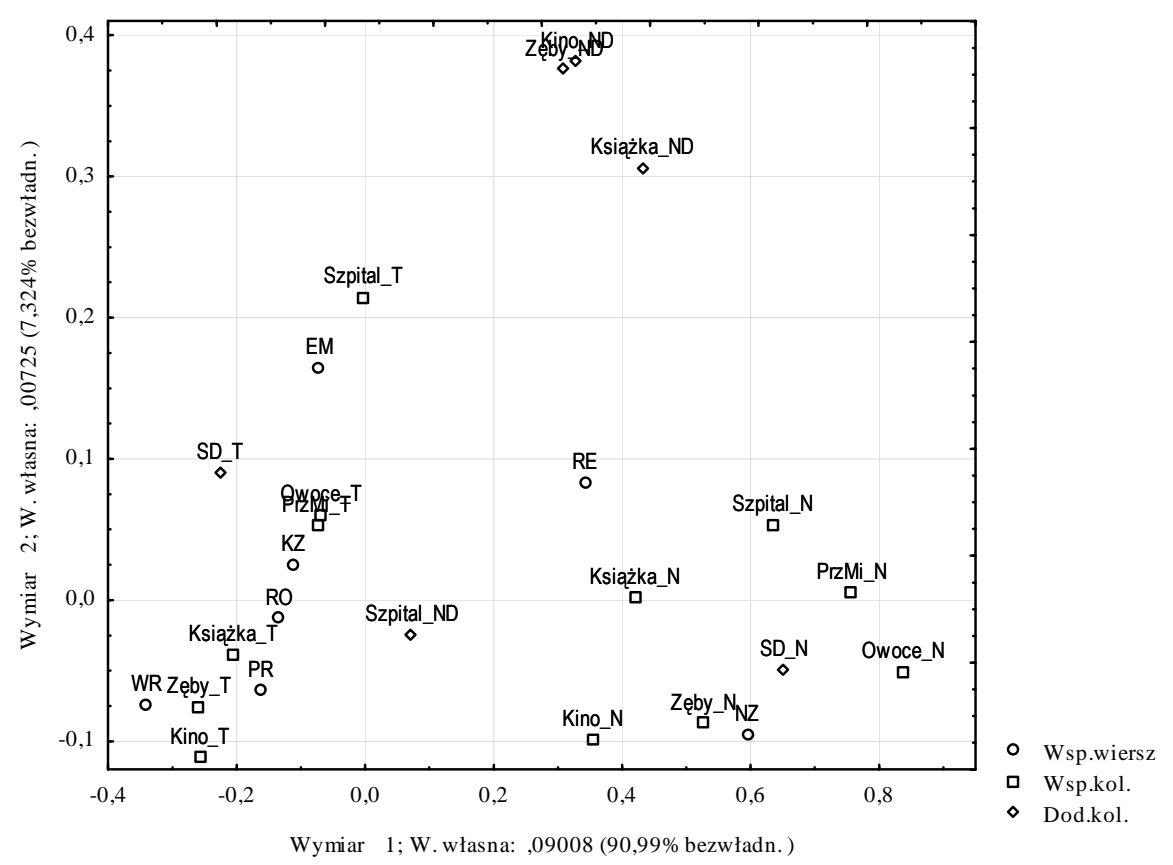

Rysunek 7. Prezentacja powiązań pomiędzy grupami gospodarstw domowych a trudnościami finansowymi dotyczącymi zaspokajania wybranych potrzeb społecznych w 2013 roku

Źródło: opracowanie własne.

W 2013 roku, podobnie jak w ubiegłych analizowanych latach, najwięcej trudności finansowych związanych z zakupem wybranych dóbr i usług miały gospodarstwa rencistów (RE) oraz gospodarstwa utrzymujące się z niezarobkowych źródeł (NZ), z tym że te ostatnie największe problemy miały z zakupem produktów spożywczych.

Punkty z atrybutem ND, tj. Kino_ND, Zęby_ND oraz Książka_ND, tworzą odrębne skupisko.

Na swobodny zakup artykułów spożywczych mogło sobie pozwolić ok. $19 \%$ gospodarstw domowych, a 13\% - na zakup książki. Trudności finansowe związane z leczeniem szpitalnym miało mniej niż $1 \%$ gospodarstw, natomiast ok. 3\% - z kupnem artykułów spożywczych. 


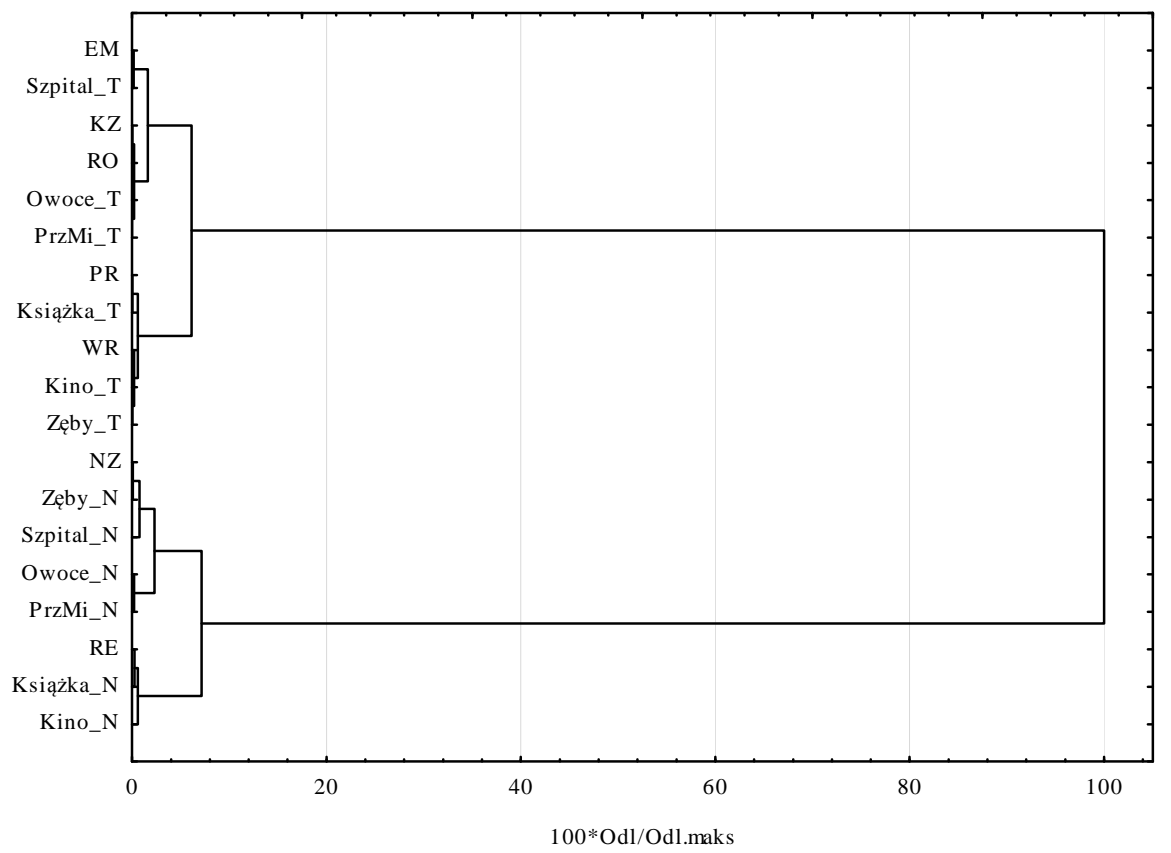

Rysunek 8. Skupiska grup gospodarstw domowych oraz wybranych potrzeb społecznych badanych w 2013 roku

Źródło: opracowanie własne.

Zależności widoczne na rysunku 7 potwierdza układ skupisk na dendrogramie (rysunek 8). Trudności finansowe związane $\mathrm{z}$ zakupem wyżywienia i usług medycznych w największym stopniu dotyczą gospodarstw domowych utrzymujących się z niezarobkowych źródeł (NZ), natomiast gospodarstwa rencistów (RE) mają problemy finansowe związane $\mathrm{z}$ zakupem książki i biletu do kina.

Kolejnym krokiem przeprowadzanej analizy jest sprawdzenie, czy w znaczący sposób zmieniło się ułożenie punktów reprezentujących gospodarstwa domowe (wiersze) oraz potrzeby społeczne (kolumny) na przestrzeni 11 lat. W tym celu porównano wykresy punktów reprezentujących wiersze dla danych z 2003 oraz z 2013 roku oraz wykresy punktów reprezentujących kolumny dla danych z takich samych lat.

Na rysunku 9 przedstawiono ułożenie punktów reprezentujących wiersze (gospodarstwa domowe) w 2003 roku. Natomiast rysunek 10 prezentuje układ punktów (wierszy) dla danych z 2013 roku. 


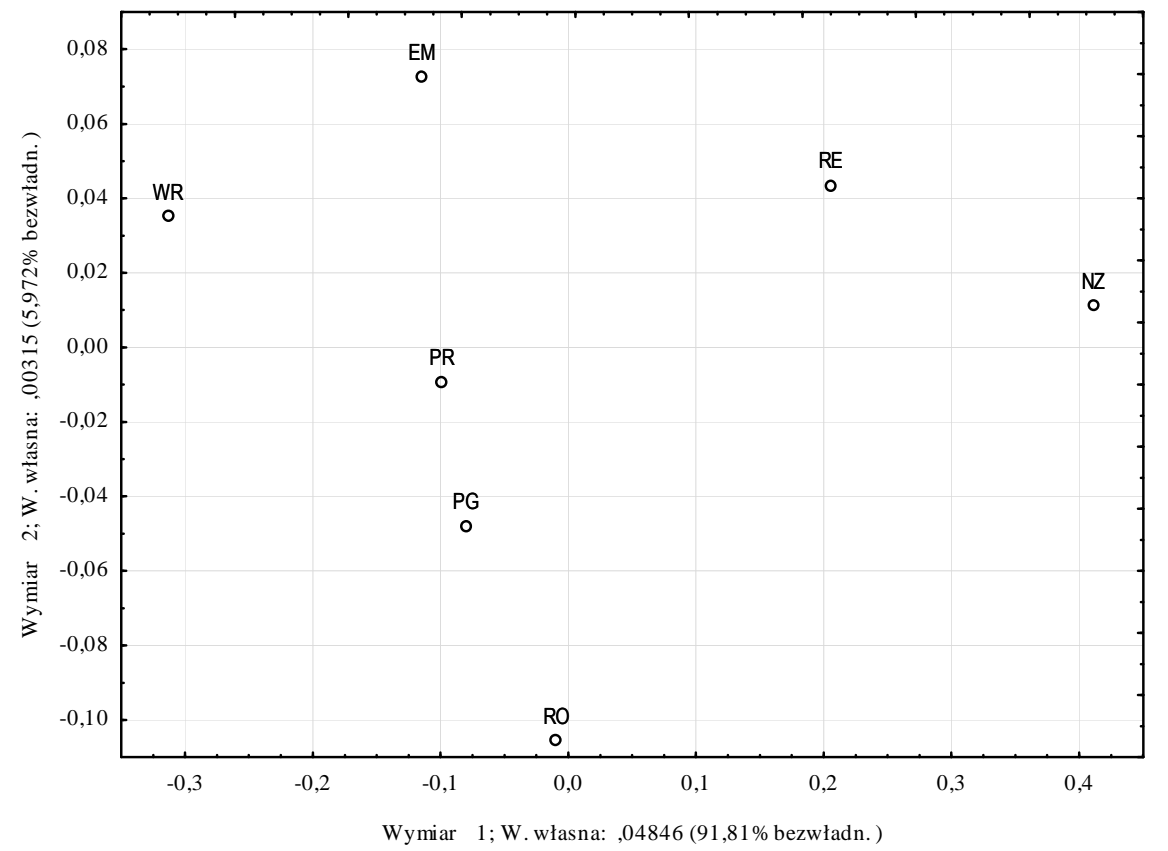

Rysunek 9. Reprezentacja gospodarstw domowych analizowanych w 2003 roku Źródło: opracowanie własne.

Położenie punktów na wykresach na przestrzeni analizowanych lat nie uległo zmianom, brak zauważalnych tendencji.

Najbardziej na prawo względem środka osi poziomej umiejscowione są punkty reprezentujące gospodarstwa domowe rencistów (RE) oraz gospodarstwa utrzymujące się z niezarobkowych źródeł (NZ). Natomiast najbardziej na lewo względem środka osi poziomej położony jest punkt WR, reprezentujący gospodarstwa domowe utrzymujące się z pracy na własny rachunek. Gospodarstwa emerytów (EM) na obu wykresach umiejscowione są w znacznej odległości od pozostałych punktów oraz od środka układu współrzędnych. Oznacza to, że profil grupy gospodarstw domowych emerytów różni się znacznie od profili pozostałych rozważanych grup gospodarstw domowych.

Zauważyć można, że przeobrażeniu ulega struktura analizowanych gospodarstw. W 2003 roku wyodrębnione były gospodarstwa pracowników (PG), których nie ma już w badaniu z 2013 roku, pojawiły się natomiast gospodarstwa domowe utrzymujące się z kilku źródeł (KZ). 


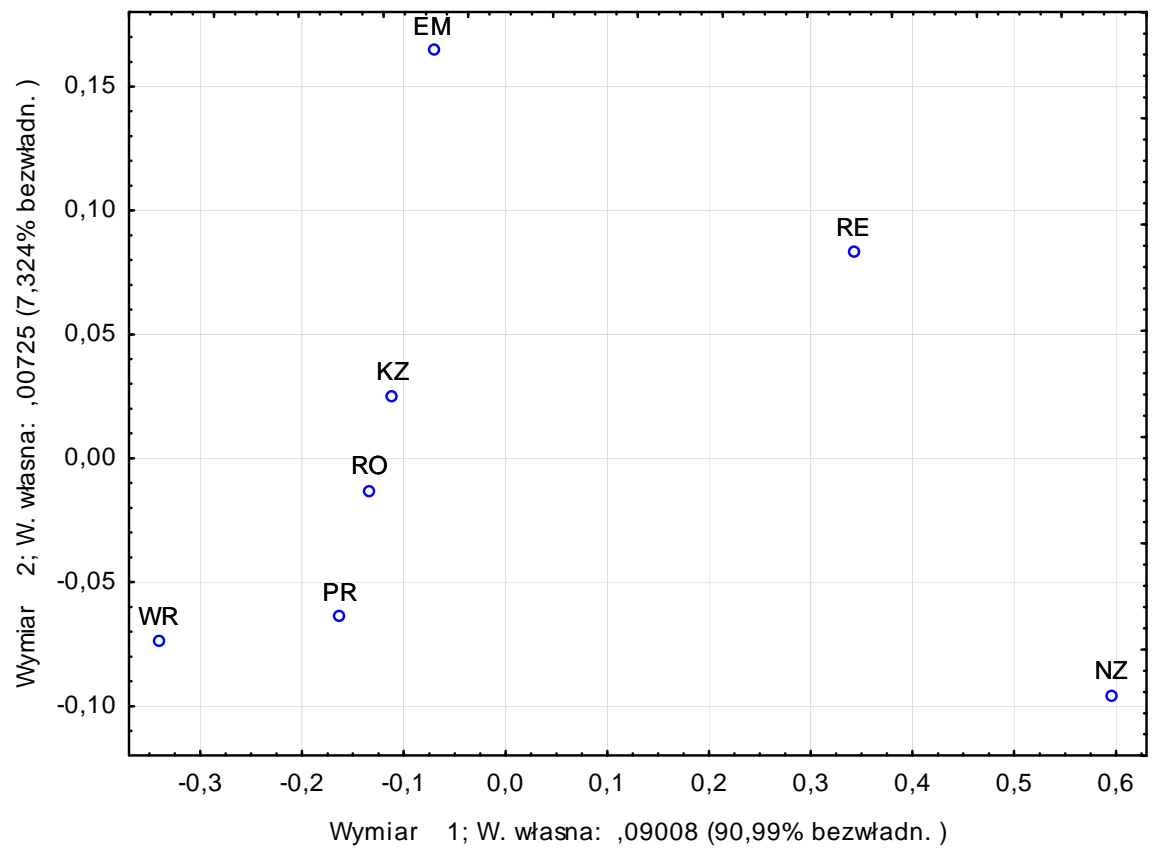

Rysunek 10. Reprezentacja gospodarstw domowych analizowanych w 2013 roku Źródło: opracowanie własne.

Rysunki 11 i 12 ukazują ułożenie punktów reprezentujących potrzeby społeczne i stały dochód dla danych z 2003 i 2013 roku. Na obu rysunkach zauważyć można, że potrzeby powiązane $\mathrm{z}$ trudnościami finansowymi położone są na prawo względem środka osi poziomej. Natomiast punkty reprezentujące potrzeby społeczne, które gospodarstwa domowe mogły swobodnie zaspokajać, położone są na lewo od środka osi. Punkty te tworzą bardziej zbite skupisko, odległości między nimi są mniejsze w porównaniu z odległościami między punktami reprezentującymi potrzeby związane z trudnościami finansowymi.

Na szczególną uwagę zasługuje położenie punktu Szpital_T (rysunek 11). Jest on umiejscowiony w bardzo bliskiej odległości od środka osi poziomej, czyli profil tego punktu jest bardzo zbliżony do profilu przeciętnego. Ma największą masę $(0,163)$ spośród analizowanych kolumn, co oznacza, że ponad 16\% ankietowanych gospodarstw domowych nie ma trudności finansowych związanych z leczeniem szpitalnym. Zupełnie inaczej sytuacja ma się w 2013 roku, w którym jedynie 6,4\% gospodarstw nie boryka się z takimi problemami (masa punktu Szpital_T wynosi 0,064). 


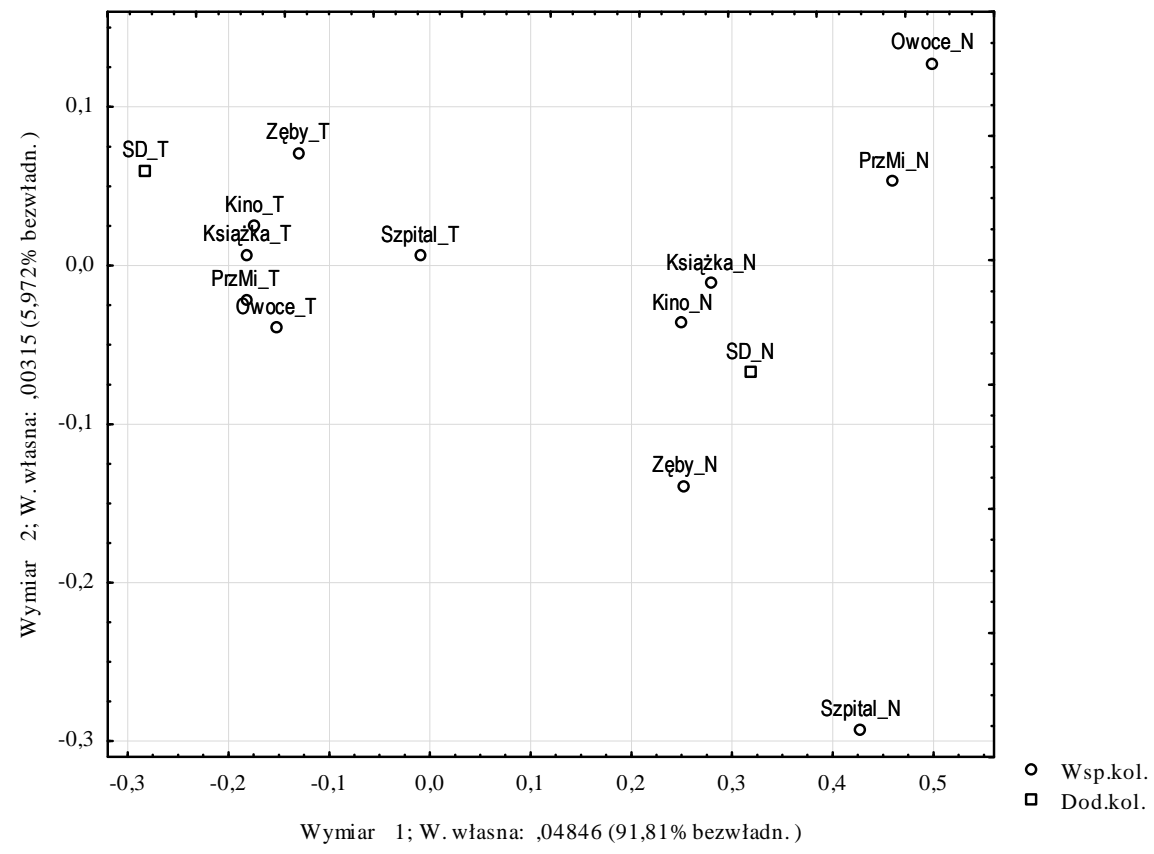

Rysunek 11. Reprezentacja potrzeb społecznych oraz punktów dodatkowych związanych ze stałym dochodem analizowanych - dane z 2003 roku

Źródło: opracowanie własne.

Zauważyć należy pojawiający się trend związany z zakupem artykułów spożywczych. W 2003 roku ok. 12\% gospodarstw domowych mogło dokonywać zakupu wyżywienia bez trudności finansowych, natomiast w 2013 na ten sam zakup mogło sobie pozwolić już ok. 19\% gospodarstw.

Punkty reprezentujące potrzeby, które nie dotyczą analizowanych gospodarstw domowych, tzn. Kino_ND, Książka_ND, Zęby_ND, tworzą odrębne skupisko umiejscowione w prawej górnej ćwiartce wykresu. Wyjątkiem wśród tych punktów jest punkt Szpital_ND, który położony jest pomiędzy skupiskami punktów reprezentujących potrzeby związane $\mathrm{z}$ trudnościami finansowymi związanymi z ich zaspokajaniem oraz punktów związanych $\mathrm{z}$ brakiem tych trudności. Może to oznaczać, że pomimo deklaracji gospodarstw domowych o trudnościach finansowych związanych z leczeniem szpitalnym bądź o braku takich problemów, często nie muszą one korzystać $\mathrm{z}$ tej formy ochrony zdrowia. 


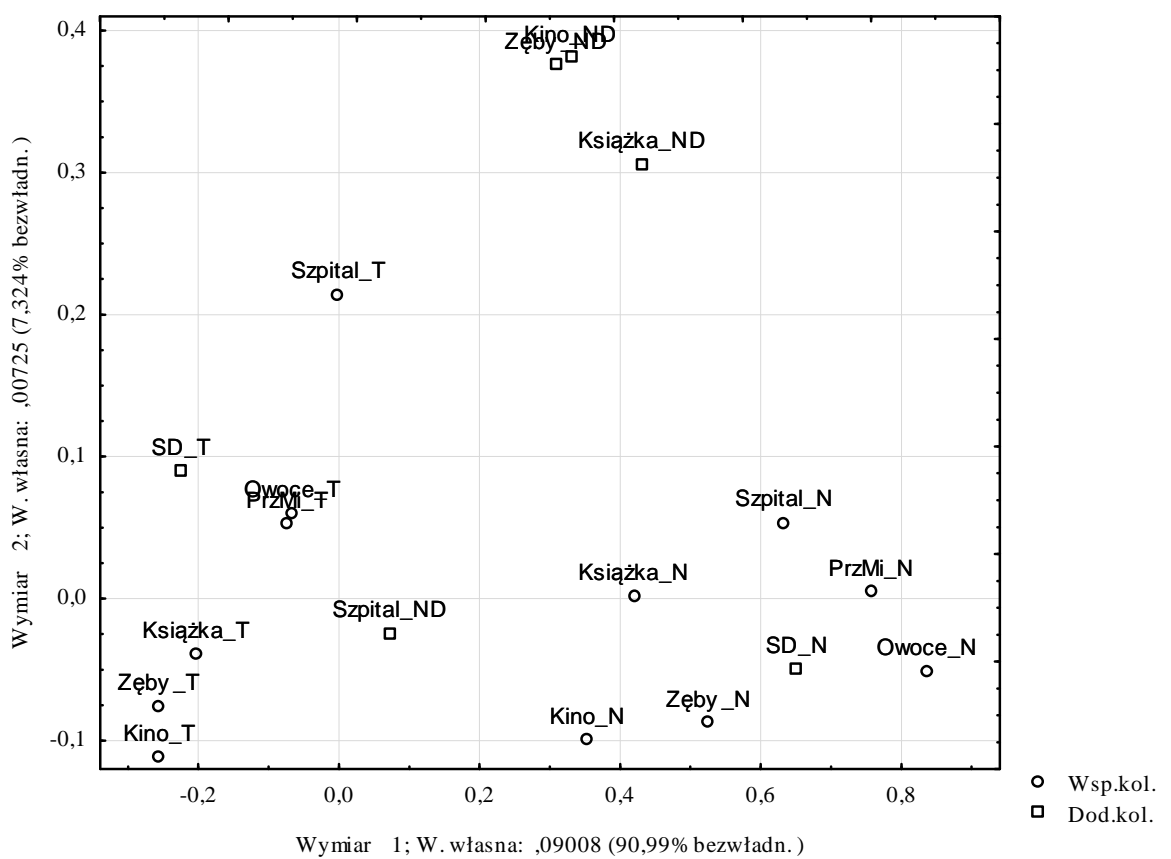

Rysunek 12. Reprezentacja potrzeb społecznych oraz punktów dodatkowych związanych ze stałym dochodem - dane z 2013 roku

Źródło: opracowanie własne.

\section{PODSUMOWANIE}

Wyniki badań nad powiązaniami grup gospodarstw domowych z wybranymi potrzebami społecznymi pod kątem trudności finansowych dotyczących ich zaspokajania pozwalają stwierdzić, że gospodarstwa domowe utrzymujące się z niezarobkowych źródeł oraz gospodarstwa rencistów mają największe trudności finansowe $\mathrm{z}$ zaspokajaniem wybranych potrzeb społecznych. W ostatnich latach, tj. od 2011 roku można zauważyć, że problemy finansowe gospodarstw utrzymujących się z niezarobkowych źródeł dotyczą głównie wyżywienia, natomiast renciści borykają się przede wszystkim z brakiem środków na zakup książki i biletu do kina.

Trudno jednoznacznie stwierdzić, czy istotnie potrzeby wyższego rzędu, do jakich zalicza się uczestnictwo w wybranych formach kultury, są związane $\mathrm{z}$ większymi trudnościami finansowymi niż potrzeby związane $\mathrm{z}$ zakupem wyżywienia. Nie bez znaczenia jest fakt, że potrzeby dotyczące wyżywienia są bardziej powszechne i zaspokajane są znacznie częściej. Do kina chodzi 
się zwykle raz na jakiś czas, natomiast posiłki spożywa się codziennie. Podobnie jest $\mathrm{z}$ ochroną zdrowia. Leczenie zębów i pobyt w szpitalu nie występują tak często jak potrzeba jedzenia. Jednak skutki zaniedbania zdrowia są bardziej dokuczliwe niż rezygnacja z pewnych form kultury. Ból zęba jest na pewno bardziej dominujący niż chęć pójścia do kina.

$\mathrm{Na}$ przestrzeni analizowanych lat zauważono, że wzrasta liczba gospodarstw, które stać na zakup wyżywienia. W roku 2003 było ich ok. 12\%, podczas gdy w 2013 już ok. 19\%.

W 2003 roku ok. 16\% gospodarstw domowych nie miało trudności finansowych związanych z leczeniem szpitalnym, podczas gdy w 2007 było ich już tylko $6 \%$ i poziom ten utrzymał się do roku 2013. Być może jest to spowodowane wprowadzeniem do kwestionariusza odpowiedzi Szpital_ND. Leczenie zębów w analizowanym okresie odbywa się bez trudności finansowych dla ok. $10 \%$ gospodarstw.

Na stałym poziomie ok. $10 \%$ jest liczba gospodarstw, które stać na zakup biletu do kina. Natomiast wzrosła liczba gospodarstw, które mogą sobie pozwolić na zakup książki, z 10\% w 2003 do 13\% w 2013 roku.

Potrzeby wyższego rzędu mają to do siebie, że są mniej istotne dla biologicznego przetrwania organizmu. Mogą być zaspokojone w późniejszym okresie bądź zaniknąć. Gospodarstwa domowe biorące udział w badaniu „Diagnoza społeczna” mogły określić, które potrzeby ich nie dotyczą (ND). Mogły to być również potrzeby, które zaniknęły ze względu na ograniczone środki finansowe. Niepokojące jest zjawisko, gdy członkowie gospodarstwa domowego twierdzą, że nie czują potrzeby zakupu książki czy pójścia do kina. Jak wspominał Maslow (2006). życie na poziomie wyższych potrzeb oznacza większą efektywność biologiczną, długowieczność, mniej chorób itp. - przyczynia się zarówno do przetrwania, jak i wzrastania.

Informacja o tym, że gospodarstwa domowe utrzymujące się z niezarobkowych źródeł innych niż emerytura i renta oraz gospodarstwa rencistów mają od lat trudności finansowe $\mathrm{z}$ zaspokajaniem potrzeb społecznych, powinna być przesłanką do zmiany polityki społecznej w taki sposób, by skutecznie wpłynęła na poprawę ich sytuacji.

\section{LITERATURA}

Diagnoza spoteczna: zintegrowana baza danych, www.diagnoza.com (06.03.2014).

Doyal L., Gough I. (1991), A Theory of Human Need, Macmillan, London.

Gatnar E., Walesiak M. (red.) (2011), Analiza danych jakościowych i symbolicznych z wykorzystaniem programu $R$, Wydawnictwo C.H. Beck, Warszawa.

Greencare M.J. (1984), Theory and Application of Correspondence Analysis, Academic Press, London. 
Kurzynowski A. (red.) (2003), Polityka społeczna, Szkoła Główna Handlowa - Oficyna Wydawnicza, Warszawa.

Maslow A.H. (2006), Motywacja i osobowość, Wydawnictwo Naukowe PWN SA, Warszawa. Panek T. (red.) (2007), Statystyka spoteczna, PWE, Warszawa.

Stanisz A. (2007), Przystępny kurs statystyki z zastosowaniem STATISTICA PL na przyktadach z medycyny. Tom 3. Analizy wielowymiarowe, Statsoft Polska Sp. z o.o., Kraków.

Szczepański J. (1981), Konsumpcja a rozwój człowieka. Wstęp do antropologicznej teorii konsumpcji, PWN, Warszawa.

\section{ANALYSIS OF MEETING SOME SOCIAL NEEDS DEPENDING ON HOUSEHOLD LIVELIHOOD}

A b s t r a ct. Social needs are classified according to different criteria. It is often assumed that physiological and safety needs are satisfied first. The aim of this paper is to check which groups of households separated due to livelihood have the greatest financial difficulties meeting the most fundamental level of need, and which households can easily fulfill the needs of a higher level.

K e y w or d s: social needs, correspondence analysis, cluster analysis. 
